\title{
Assessment of Social Responsibility Initiatives of Corporate Organizations on the Entrepreneurial Development of Ishiagu, Ebonyi State Nigeria
}

\author{
Eke, K. A. ${ }^{1}$, Balogun, R. B. ${ }^{2}$, Ivoke, H. I. ${ }^{2}$, Kalejaiye-Matti, R. B. ${ }^{3}$, Alasi, T. K. ${ }^{1}$ \\ ${ }^{1}$ Department of Science Laboratory Technology, Federal College of Agriculture, Ishiagu, Ebonyi, Nigeria \\ ${ }^{2}$ Department of Horticulture and Landscape Technology, Federal College of Agriculture, Ishiagu, Ebonyi, Nigeria \\ ${ }^{3}$ Department of Animal Production Technology, Federal College of Agriculture, Ishiagu, Ebonyi, Nigeria \\ Email address: \\ kenek72@yahoo.com (Eke K. A.), balogunrb@gmail.com (Balogun R. B.), alakenny@yahoo.com (Alasi T. K.)
}

\section{To cite this article:}

Eke, K. A., Balogun, R. B., Ivoke, H. I., Kalejaiye-Matti, R. B., Alasi, T. K.. Assessment of Social Responsibility Initiatives of Corporate Organizations on the Entrepreneurial Development of Ishiagu, Ebonyi State Nigeria. Science Journal of Business and Management. Special Issue: Sustainable Entrepreneurial Developments in Agribusiness. Vol. 3, No. 5-1, 2015, pp. 50-54. doi: 10.11648/j.sjbm.s.2015030501.21

\begin{abstract}
The assessment of entrepreneurial level initiatives of Corporate Organizations who invest on communal lands without adequate impact assessment in Ishiagu, Ivo LGA of Ebonyi State, Nigeria have been carried out. This assessment spelt out the level of corporate social responsibility among other salient issues and the entrepreneurial level development of Ishiagu indigene. Beside this, other objectives include: level of compliant to environmental and socio-cultural sustainability. The findings of the study indicated a fair impact on entrepreneurial level of the inhabitant of the communities, fair ecological sustainability but poor socio-cultural sustainability. The paper concluded that legislation to enforce CSR be put in place by government and activities be monitor for compliance.
\end{abstract}

Keywords: Corporate, Social Responsibility, Entrepreneurship, Mining, Impact Assessment, Environment

\section{Introduction}

Activities of corporate organizations anywhere in the world despite its numerous socio-economic benefits are widely known to have major negative impacts on the environment and the inhabitant of these environments; especially the mining firms. The pertinent question to ask is who suffers and who gains as a consequence of these environmental hazards? It is quite ironic to note that most a times the indigenous community hosting the mining corporations are the victims. They live below the poverty line and have little to show for the abundant natural resources within their domain. It is, therefore, not out of place to expect that the mining companies which are usually multinational give entrepreneurial empowerment to the communities where exploration is taking place in order to reduce or even compensate their losses. This is the spirit behind the "corporate social responsibility".

\subsection{Corporate Social Responsibility (CSR)}

The term "corporate social responsibility" came into common use in the late 1960s and early 1970s after many multinational corporations formed the term stakeholder, meaning those on whom an organization's activities have an impact. CSR policy functions as a built-in, self-regulating mechanism whereby a business monitors and ensures its active compliance with the spirit of the law, ethical standards, and international norms. In some models, a firm's implementation of CSR goes beyond compliance and engages in "actions that appear to further some social good, beyond the interests of the firm and that which is required by law" $[1,2]$.

CSR is a process that aims to embrace responsibility for the company's actions and encourage a positive impact through its activities on the environment, consumers, employees, communities, stakeholders and all other members of the public sphere who may also be considered as stakeholders.

It also consists in the companies themselves defining, unilaterally and voluntarily, social and environmental policies by means of alternative instruments that are neither collective agreement nor legislation, and offering, in pursuit of these aims, partnership to multiple actors [3].

Corporate Social Responsibility as a way of ensuring that businesses are more responsive to the environmental and social concern of the society in which they operate [1]. The 
question is, to what extent does the CSR policy involve and partner with the community as stated in the $10^{\text {th }}$ principle of the Rio Declaration on environment and development that environmental issues are better discussed with the involvement of the people [4].

In the past, many large corporations were seen to be insensitive to the needs of society and caused much of the environmental degradation of the earth, [5]. Their motive has been how to make profit and how to satisfy their shareholders as posited by [6]. Although the situation is changing, it is imperative to wonder if the changes that are occurring have yielded expected results. In this contemporary world, many businesses, whether big or small, try in a way to care for the needs of the society in which they operate and also put in place measures to control degradation of the environment. These actions done by the companies, whether structured or not, have been embraced by both the beneficiaries and other stakeholders in that they are seen to contribute towards the development of its beneficiaries.

By adopting social responsibility measures, the businesses in a way try to increase sustainable development of their host communities. Many theorists as well as development agencies such as DFID, USAID, and the World Bank among others have argued that CSR could be considered as a tool for the attainment of sustainable development especially in developing countries. These agencies have submitted that engaging the corporate world in development agenda is one way of achieving sustainable development and compliance to global best practices and conventions [7].

\subsection{Statement of the Problems}

The challenges of corporate organizations and its socio-environmental impact on the host communities can be $\mathrm{x}$-rayed in this manner:

a) Loss of cultural heritage - most of the community's sacred grooves and forests had to be demystified to accommodate mining merchants because mining site encroach on such infrastructure. The traditional religious practices associated with such cultural infrastructure become extinct with time. Traditional practices with its attendant taboos which regulate the community are critically endangered because of abandonment by the people. In most places, this is a major source of eco-cultural tourism. It is a renewable resource and foreign exchange earner for the host communities and the country.

b) Mining sites are eye sours. Greater chunk of community's land are irreversibly degraded. Depressions created are death trap. Several people have lost their lives when they mistakenly fall into it. Water accumulating in them is breeding site for mosquito, which eventually causes fever and death.

c) Dynamites and other chemicals pollute the air during explosion, chemical seep into water bodies causing multiple deaths due to poisoning. These are common around lead mining sites, which is one of the major mineral mined in Ishiagu. d) Occupational displacement is a great threat in these major farming communities. Young men and women abandoned farming to touting and scouting for mineral merchants with peanuts as reward.

e) Rising incidence of criminality. With culture being eroded, farming being abandoned, unprepared civilization being forced on the community and no commensurate reward in the new vocation; poverty escalates. In order to beat the threat of poverty, various forms criminality becomes the order of the day.

f) Youth restiveness. In order to lay claim to the wealth coming out of their land, youth organized themselves to groups and associations to demand for a share of the resources from the mining corporations. Where their demands are not met, they resort to violence, arson and other form of negative tendencies which are strange to the culture.

g) Destruction of structures. The tremor created during blasting of rocks cracks buildings and others important structures which is never compensated for. Besides, lorry loading granite destroys roads that are supposed to last for several years. Should we call these unintended consequences of mining or poor planning? Because conventional best practices presupposes that detailed environmental impact assessment be conducted before any mining operation. This was neglected at the pre-mining stage, ignored at on-going mining stage and now the resources are finally depleted. In all, the community suffers all through.

h) Proliferation of illegal mining activities. In order to survive after abandoning farming, youth in the community resort to illegal mining, ignoring the consequence.

\subsection{Objectives of the Study}

The objectives of the study include:

1. To assess the degree of corporate organizations compliant to socio-cultural sustainability of the host community.

2. To assess the degree of economic and entrepreneurial intervention on host community by corporate organizations.

3. To assess the level of compliant to environmental sustainability and standards by mining companies.

\section{Materials and Methods}

\subsection{Description of the Study Area}

Ishiagu is Located at Latitude $5^{\circ}$ and $6^{\circ}$ north and longitude $7^{\circ}$ and $8^{\circ}$ east with an annual rainfall of $1200-1600 \mathrm{~mm}$, a mean temperature range of between $27^{\circ} \mathrm{C}-33^{\circ} \mathrm{C}$. It is made up of 11 communities with autonomous status [8]. It is a semi-urban town being a primary agricultural producer with extractive industry and education [9] as means of occupation. Within each community, compound farming is a common feature. Though, other farm sites with hamlet settlement and 
belonging to each community equally exist. Quarrying activities takes place in various parts of the community. Some of the solid minerals includes: granite, lead and salt. These activities have created series of ecological degradation and health hazards to the landscape and its inhabitant; though with some appreciable job opportunities and other socio-economic benefits. The communities are homogenous in terms of ancestral decent and farming practices [10].

\subsection{Sampling Procedure}

Permission to conduct the research was sought from the authorities of the organization under survey [11]. Questionnaires were administered personally by the researcher on the respondents. A maximum time period of two weeks was used for distribution and collection. A structured interview was conducted with the officers of the mining organizations, the only tertiary institution in the town and other well-informed local individual. In drawing the sample for this study, the researcher adopts the systematic random sampling.

Reconnaissance survey was conducted through field visits for the physical appraisal of mining sites in the town and the Federal College of agriculture. Structured questionnaires were administered and participatory approaches were employed on the respondents which comprise of civil servants, heads of organizations, students, artisans, chiefs and other professionals to source for the level of environmental degradation and corporate social responsibility by the organizations engaged in occupational activities in the community $[11,12]$. Three corporate organizations in Ishiagu community were sampled. The organizations are: Crushed Rock Industries (Ishiagu Quarry) and Setraco Construction Nig. Ltd (Ishiagu Quarry) and Federal College of agriculture. Within each community, 10 questionnaires were randomly distributed within the 11 autonomous communities. In all, 110 questionnaires were administered with 100 being valid.

\subsection{Data Analysis}

The collected data were coded, classified and subjected to descriptive statistics such as percentages and frequency distribution. This is necessary in order to determine the distribution of the respondents within the three organizations as regards to organization corporate social responsibility.

\section{Results and Discussion}

\subsection{Demographic Characteristics of the Respondents}

Table 1 showed the demographic variables of the respondents in this order: The gender ratio indicated male having $68 \%$ while female had $32 \%$.

Within the age group, 25 - 35 had 30\%, 35 - 45 had $45 \%$ and 45 and above had $25 \%$. Their level of education indicated WASC/GCE having $45 \%$ while tertiary had 55\%. The occupational preference of the respondents showed civil servant having $40 \%$, artisan $15 \%$, schooling had $25 \%$ while other professionals had $20 \%$.

Table 1. Demographic data of the respondents.

\begin{tabular}{lll}
\hline Variables & Frequency & Percentage \\
\hline a. Gender ratio & & \\
Male & 68 & 68.00 \\
Female & 32 & 32.00 \\
Total & 100 & 100.00 \\
b. Age group of the respondent & \\
25-35 & 30 & 30.00 \\
$35-45$ & 45 & 45.00 \\
45 and above & 25 & 25.00 \\
Total & 100 & 100.00 \\
c. Level of education & & \\
WASC/GCE & 45 & 45.00 \\
Tertiary & 55 & 55.00 \\
Total & 100 & 100.00 \\
d. Occupational level & & \\
Civil servant & 40 & 40.00 \\
Artisan & 15 & 15.00 \\
Students & 25 & 25.00 \\
Others professionals & 20 & 20.00 \\
Total & 100 & 100.00 \\
\hline
\end{tabular}

\subsection{Levels and Forms of Compliant to Socio - Cultural Sustainability}

The respondents' response to level of complaint to socio-cultural sustainability showed $20 \%$ indicating very inadequate while $40 \%$ indicated adequate and inadequate respectively. On the form of complaint to socio-economic sustainability, these parameters indicated on table $3 \mathrm{~b}$ indicated $40 \%$ satisfaction towards $60 \%$ non-satisfaction to the students' scholarship scheme operated by the corporate organization.

Table 2. Levels and forms of compliant to socio - cultural sustainability.

\begin{tabular}{|c|c|c|c|}
\hline Variables & ratings & freq & $\%$ \\
\hline \multicolumn{4}{|c|}{ a. Level of compliant to socio - cultural sustainability } \\
\hline & Very Adequate & -- & -- \\
\hline & Adequate & 40 & 40.00 \\
\hline & Very inadequate & 20 & 20.00 \\
\hline & Inadequate & 40 & 40.00 \\
\hline & Undecided & - & - \\
\hline \multirow{2}{*}{\multicolumn{4}{|c|}{$\begin{array}{l}\text { Total } \\
\text { b. Form of compliant to socio - cultural sustainability } \\
\text { i. Levels of communal of communal unrest }\end{array}$}} \\
\hline & & & \\
\hline & Regular & 80 & 80.00 \\
\hline & Irregular & & 20 \\
\hline Total & & 100 & 100.00 \\
\hline \multicolumn{4}{|c|}{ ii. Forms of communal of communal unrest } \\
\hline \multicolumn{4}{|c|}{$\begin{array}{l}\text { 1. Disruptic } \\
\text { mining sites }\end{array}$} \\
\hline \multirow{2}{*}{\multicolumn{2}{|c|}{$\begin{array}{l}\text { ii. Closure of organizations' gate } \\
\text { iii. Abduction of company's worker }\end{array}$}} & 30 & 30.00 \\
\hline & & 10 & 10.00 \\
\hline $\begin{array}{c}\text { iv. De } \\
\text { machinery }\end{array}$ & of company's & 20 & 20.00 \\
\hline
\end{tabular}

The employment opportunities showed a balance of $50 \%$ for both satisfaction and non-satisfaction. The infrastructural development ratings indicated $30 \%$ satisfaction and $70 \%$ indicated non-satisfaction.

The various forms and ratings of communal unrest towards non-compliant to terms of agreed corporate social responsibility includes the following: $40 \%$ responded to 
disruption of production on mining site, $30 \%$ indicated outright closure of company gate thus preventing workers entrance, $10 \%$ indicates abduction of company staff, $20 \%$ indicated cases of destruction of company machinery (Table 2).

Table 3. Intervention in social-economic and Degree of entrepreneurial Intervention on the host community.

\begin{tabular}{|c|c|c|c|}
\hline Variables & Rating & Freq & $\%$ \\
\hline \multicolumn{4}{|c|}{ a. Intervention in social-economic welfare } \\
\hline & Adequate & 40 & 40.00 \\
\hline & Very inadequate & 30 & 30.00 \\
\hline & Inadequate & 30 & 30.00 \\
\hline & Adequate & 40 & 40.00 \\
\hline Total & & & 100 \\
\hline \multicolumn{4}{|c|}{$\begin{array}{l}\text { b. Degree and forms of entrepreneurial Intervention } \\
\text { i. Student scholarship scheme }\end{array}$} \\
\hline & Satisfactory & 40 & 40.00 \\
\hline & Non- satisfactory & 60 & 60.00 \\
\hline Total & & 100 & 100.00 \\
\hline \multicolumn{4}{|c|}{ ii. Employment opportunities } \\
\hline & Satisfactory & 50 & 50.00 \\
\hline & Non- satisfactory & 50 & 50.00 \\
\hline Total & & 100 & 100.00 \\
\hline
\end{tabular}

The respondents rate the socio-economic and environmental welfare of the corporate organizations in this order $40 \%$ claimed adequate, $30 \%$ claimed very inadequate and inadequate respectively. Equally, the degree and forms of entrepreneurial intervention indicated the following: student scholarship, $60 \%$ is not satisfactory while $40 \%$ affirmed satisfactory. Employment opportunities indicated a balance of $50 \%$ for not satisfactory and satisfactory (Table 3 ).

Table 4. Level and forms of compliant to environmental sustainability.

\begin{tabular}{|c|c|c|c|}
\hline Variables & ratings & freq & $\%$ \\
\hline \multicolumn{4}{|c|}{ a. Level of compliant to environmental sustainability } \\
\hline & Very Adequate & -- & -- \\
\hline & Adequate & 40 & 50.00 \\
\hline & Very inadequate & 30 & 20.00 \\
\hline & Inadequate & & 20 \\
\hline & Undecided & 10 & 10.00 \\
\hline Total & & 100 & 100.00 \\
\hline \multicolumn{4}{|c|}{$\begin{array}{l}\text { b. Forms of compliant to environmental sustainability } \\
\text { i. Grading and tarring of township road network }\end{array}$} \\
\hline & Satisfactory & 40 & 40.00 \\
\hline & Non- satisfactory & 60 & 60.00 \\
\hline Total & & 100 & 100.00 \\
\hline \multicolumn{4}{|c|}{ ii. Construction of township drainages } \\
\hline & Satisfactory & - & - \\
\hline & Non- satisfactory & 100 & 100.00 \\
\hline \multicolumn{4}{|c|}{ iii. Provision of portable water } \\
\hline & Satisfactory & 30 & 30.00 \\
\hline & Non- satisfactory & 70 & 70.00 \\
\hline Total & & 100 & 100.00 \\
\hline
\end{tabular}

\subsection{Level and Forms of Complaint to Environmental Sustainability}

The level of complaint to environmental sustainability showed the following trend: $40 \%$ indicated the complaint is adequate, $10 \%$ is undecided while $30 \%$ affirmed very inadequate while $20 \%$ showed inadequate.
On the forms of complaint to environmental sustainability, the following variables were employed: Grading and tarrying of township road network, $40 \%$ indicated satisfactory, $60 \%$ showed non-satisfactory. Construction of township drainages, $100 \%$ of the respondents indicated non-satisfactory. On the provision of portable water, $70 \%$ showed non-satisfactory while $30 \%$ showed satisfactory.

\subsection{Discussion}

The levels and forms of socio-economic and environmental intervention in the welfare of the host community in the study area as could be inferred from the results are below average. This is evident in the series of social unrest and agitation for significant corporate social responsibility on the corporate organizations operating in Ishiagu. This situation compares with what is obtainable in most developing countries that neither know their rights nor lack effective legislation for enforcing CSR. This finding is consistent with [13] wherein they inferred that in the absence of mandatory legislation on corporate social responsibility, host communities would remain ecologically degraded and impoverished.

Tchopp [14] on his part averred that corporate social responsibility is a mere positioning strategy. He observed that where it is claimed to be used, it does not provide useful information to stakeholder due to lack of comparability and consistency standards and guidelines. This is equally the case in the study area.

Documentary evidence indicated inadequate or perhaps non-existence transparent financial reporting by the organizations as at the time of this research. Among the three organizations, one is educational while the two others are mining and construction industries and not listed on Nigeria stock exchange. This implies that their annual report is not available and besides, their websites is not revealing such information.

\section{Conclusion}

\subsection{Conclusion}

Corporate Social Responsibility presents itself as a very useful tool for the implementation of sustainable development if it is well/adequately applied. It is important for corporate organization, especially mining companies to have the developmental interest of their local communities at heart. They need to ensure that their activities in the communities affect the local people in the most minimum way possible.

\subsection{Recommendations}

From the findings of the results, the following recommendations are essential:

There should be Corporate Social Responsibility policies to govern corporate organization and community activities.

The community should be major stakeholders in the affairs of how the organizations operate.

Policy should focus on strict implementation of impact assessment. Through this CSR to the community would have 
been upheld.

That as much as companies have responsibilities; host communities should also have responsibilities for the companies through ensuring peaceful co-existence.

\section{References}

[1] Utiing, P. (2000) Business Responsibility for sustainable Development, United Nations Research Institute for Social Development (Geneva 2000), occasioned paper No. 2.

[2] Binda, A., Palenberg, M. and Witte, M. J. (2007) Engaging in Development: Results of an International Benchmarking study" GPPi Research papers series No. 8, Berlin; Global public policy institute.

[3] Gerard, F. (2003) Corporate Social Responsibility: Envisioning its social implications. The Jus Semper Global Alliance: A TLWNSI ISSUE ESSAY.

[4] Bagley, C. E. (1999) Managers and the legal Environment: strategies for the $21^{\text {st }}$ Century, third Ed. West Educational Publishing Company, Ohio.

[5] Utting, P. (2005) Corporate Responsibility and the movement of Business Development in Practice. Vol.15, issue 3 \& 4.

[6] Aderemi, P. J. (2008) Governance and Corporate Social Responsibility in Nigeria. Bendel Newspaper Company (Nig.); Nigerian Observer online Edition.
[7] Hones, P. (2007) Corporate Social Responsibility: An implementation Guide for Business. International Institute for sustainable Development.

[8] Anyata, E. U. (2001) Ishiagu in cultural perspective. Alphabet Nigeria, Publishers, Owerri. 6-7

[9] Areola, O, Iruegbe, O. Ahmed, K; Adeleke, B and Leong G. C. (2001) Certificate Physical and Human Geography for senior secondary schs. Unui. Press Plc. 382 -384.

[10] Ebii, C. O. (2003) Farming systems and Brush fire culture: An Environmental issue in Ishiagu, Ebonyi State, Nigeria. Biweekly Seminar series FCAI PP.3

[11] Chambers, R. (1980) Short cut methods in information gathering for the Rural Development projects paper for World Bank Agricultural sector. Symposia in: Tropical soil Biology and fertility: A Hand book of methods. 89-100

[12] Beebe, J. L. (1985) Rapid Rural Appraisal: The critical first step in farming project systems Approach to Research, farming systems. In tropical soul Biology and fertility. A Hand book of methods. $89-100$.

[13] Deegan, C. M and Ranking, M (1996) "Do Australian companies report environmental news objectively? An analysis of environmental disclosures by firms prosecuted successfully by the environmental protection authority". Accounting, Auditing and accountability Journal, Vol 9 (2): 50-67.

[14] Tchopp, D. (2003) "It's time for triple Bottom line Reporting" CPA Journal, Vol. 73 (12): 11. 